\title{
« The Vulgar Spirit of Blogging: On Language, Culture, and Power in Persian Weblogistan ». American Anthropologist, Vol. 106, Issue 4, (December 2004), pp. 651-662.
}

\section{Marcus Michaelsen}

\section{(2) OpenEdition}

\section{Journals}

Édition électronique

URL : http://journals.openedition.org/abstractairanica/6560

DOI : 10.4000/abstractairanica.6560

ISSN : 1961-960X

Éditeur :

CNRS (UMR 7528 Mondes iraniens et indiens), Éditions de l'IFRI

Édition imprimée

Date de publication : 15 mai 2006

ISSN : 0240-8910

\section{Référence électronique}

Marcus Michaelsen, « «The Vulgar Spirit of Blogging: On Language, Culture, and Power in Persian Weblogistan ». American Anthropologist, Vol. 106, Issue 4, (December 2004), pp. 651-662. », Abstracta Iranica [En ligne], Volume 27 | 2006, document 335, mis en ligne le 02 janvier 2007, consulté le 25 septembre 2020. URL : http://journals.openedition.org/abstractairanica/6560 ; DOI : https://doi.org/ 10.4000/abstractairanica.6560

Ce document a été généré automatiquement le 25 septembre 2020.

Tous droits réservés 


\title{
« The Vulgar Spirit of Blogging: On Language, Culture, and Power in Persian Weblogistan ». American Anthropologist, Vol. 106, Issue 4, (December 2004), pp. 651-662.
}

\author{
Marcus Michaelsen
}

Bien que les weblogs iraniens aient suscité beaucoup d'intérêt journalistique, il n'existe guère d'études scientifiques en langues européennes se consacrant au phénomène de ces journaux (intimes) en ligne de contenu très varié. Le présent article tente de combler cette lacune en allant, dans son analyse, au-delà de l'exaltation générale quant aux transformations sociales qui seraient la conséquence de l'appropriation par la jeunesse iranienne surtout, de ce nouveau moyen de communication. Se basant sur l'observation participante ainsi que sur une analyse de contenu, l'A. étudie un débat sur le niveau et le style de langage dans les weblogs : tandis qu'une partie des webloggers déplore l'emploi du langage familier et " ordinaire " peu respectueux des règles de la langue persane, un deuxième groupe considère le « weblogistan » avant tout comme un espace de liberté permettant de transgresser les normes tant linguistiques que culturelles. Selon l'A., il s'agit d'un conflit hégémonique dans le cyberespace entre intellectuels exclus des médias habituels et un public plus grand fuyant les restrictions de la société. Il réussit ainsi à montrer non seulement de quelle manière statut social et popularité se construisent au sein de la communauté virtuelle des webloggers, mais aussi comment la réalité sociale et politique de l'Iran actuel influence le comportement des acteurs en ligne. 
INDEX

Thèmes : 12.1. Iran

\section{AUTEURS}

MARCUS MICHAELSEN

IFRI - Téhéran 